\title{
Cell-specific expression of X-linked inhibitor of apoptosis in the anterior pituitary of streptozotocin-induced diabetic rats
}

\author{
Ana I Arroba ${ }^{1}$, Alfonso M Lechuga-Sancho ${ }^{1}$, Laura M Frago ${ }^{1,2}$, Jesús Argente ${ }^{1,2}$ and Julie A Chowen ${ }^{1}$ \\ ${ }^{1}$ Department of Endocrinology, Hospital Infantil Universitario Niño Jesús, Madrid, Spain \\ ${ }^{2}$ Department of Paediatrics, Universidad Autónoma de Madrid, Madrid, Spain \\ (Requests for offprints should be addressed to J A Chowen who is now at Hospital Infantil Universitario Niño Jesús, Servicio de Endocrinología, Avenida \\ Menéndez Pelayo, 65, 28009 Madrid, Spain; Email: jachowen@telefonica.net)
}

\begin{abstract}
Cell death is increased in the anterior pituitary of poorly controlled diabetic rats, but anti-apoptotic mechanisms are also activated. We hypothesized that specific cell types are selectively protected against diabetes-induced cell death. To determine when anti-apoptotic mechanisms are activated, streptozotocin-induced diabetic rats were killed after 1, 4, 6 and 8 weeks of evolution. Anterior pituitaries were processed for western blot analysis to determine changes in the intrinsic cell death pathway and upstream kinases involved in cell protection mechanisms. An increase in cell death was detected by ELISA at 4 weeks of diabetes. TUNEL labelling demonstrated that this corresponded to death of primarily lactotrophs, a few somatotrophs, and no thyrotrophs, corticotrophs or gonadotrophs. Levels of phosphorylated (p) Akt were increased at 1 week of diabetes, while pERK1/2 levels increased at 4 weeks and pJNK at 6 weeks. Activation of
\end{abstract}

caspase 3 decreased and anti-apoptotic members of the $\mathrm{Bcl}-2$ protein family increased as early as 1 week after diabetes onset. These changes were coincident with increased IGF-I receptor levels. Levels of X-linked inhibitor of apoptosis protein (XIAP) increased significantly after 6 weeks of diabetes, as did activation of nuclear factor (NF) $\mathrm{KB}$. Double immunohistochemistry indicated that XIAP was expressed in less than $1 \%$ of lactotrophs and gonadotrophs, approximately $50 \%$ of somatotrophs and more than $90 \%$ of corticotrophs and thyrotrophs. These results suggest that some cell survival mechanisms are rapidly activated in the anterior pituitary, even before increased cell death can be detected, while others are more delayed. Furthermore, both pituitary cell death and expression of protective mechanisms such as XIAP are celltype specific.

Journal of Endocrinology (2007) 192, 215-227

\section{Introduction}

Poorly controlled diabetes mellitus type 1 results in numerous secondary complications, including disruption of all endocrine axes (Bestetti et al. 1985, Valimaki et al. 1999). Modifications in the cellular composition of the anterior pituitary could be involved in these endocrine changes, as this gland undergoes increased cell death in poorly controlled diabetes mellitus (Arroba et al. 2003, 2005). Furthermore, this increased cell death is cell-type specific, with lactotrophs being one of the most highly affected cell types (Arroba et al. 2003). Indeed, turnover of lactotrophs and somatotrophs has been reported to be more susceptible than that of other pituitary cell types to changes in the hormonal environment (Oishi et al. 1993).

There are two major apoptosis signalling pathways (Gupta 2001), the death receptor or extrinsic pathway (Ashkanazi \& Dixit 1998) and the mitochondrial or intrinsic pathway (Zamzami \& Kroemer 2001). At 8 weeks of poorly controlled diabetes, caspase 8 , the prototypical caspase of the extrinsic cell death pathway (Boldin et al. 1996, Wajant 2002), is activated and colocalizes to lactotrophs (Arroba et al. 2005), possibly explaining their increased death rate. However, pituitary levels of proteins involved in the intrinsic cell death pathway, including members of the Bcl-2 family and the effector caspases 3, 6 and 7, are either unchanged or balanced towards cell survival (Arroba et al. 2005). Likewise, levels of $\mathrm{X}$-linked inhibitor of apoptosis (XIAP) are increased in the anterior pituitary, but not in lactotrophs (Arroba et al. 2005), suggesting that it may be involved in the protection of other cell types.

At least two intracellular signalling pathways, orchestrated by phosphatidylinositol-3 kinase/Akt and mitogen-activated protein kinases (MAPKs), are involved in cell survival mechanisms. Extracellular signal-regulated kinase (ERK) is a member of the MAPK family and in general is activated by growth factors and transduces signals to promote cell proliferation and survival (Yoon \& Seger 2006). Indeed, both MAPKs and Akt have been implicated in the secondary effects of diabetes, with inhibition of Akt and ERKs promoting cell death in different tissues (Allen et al. 2005, Zdychova \& Komers 2005). Conversely, JNK, another 
MAPK family member, becomes activated by a variety of stress signals and is involved in the induction of apoptotic cell death (Bonny et al. 2005). However this kinase is also associated with activation of inhibitors of caspases (IAPs), including XIAP, through NFkB (Sanna et al. 1998, Stehlik 1998, Xiao et al. 2002, Zou et al. 2004).

Insulin-like growth factor (IGF)-I modulates pituitary cell turnover and function (Oomizu et al. 1998, Fernandez et al. 2004, 2005) and acts through the Akt and MAPK signalling pathways. As circulating IGF-I levels are reduced in diabetes (Olchovsky et al. 1991, Busiguina et al. 1996) and decreased IGF-I signalling has been implicated in increased apoptosis in various tissues in response to diabetes (Russell et al. 1999, Gerhardinger et al. 2001), it is conceivable that it plays an important role in the modification of cell turnover in the pituitary of diabetic rats.

Activation of cell protection mechanisms in the anterior pituitary may occur in response to the increase in cell death or they could be rapidly activated in the diabetic process in an attempt to inhibit or delay cell death. Furthermore, although the intrinsic cell death pathway is not activated at 8 weeks of diabetes, it is conceivable that it is activated earlier and is then inhibited. Therefore, the aim of this study was to determine the time course of activation of the intracellular signalling pathways associated with cell survival mechanisms and of the intrinsic cell death pathway in the pituitary of rats with poorly controlled diabetes mellitus. To determine which cell types may be selectively protected against diabetes-induced cell death, colocalization studies of anterior pituitary hormones and XIAP were performed.

\section{Materials and Methods}

\section{Material}

Electrophoresis reagents were from Bio-Rad. All chemicals were purchased from Sigma or Merck unless otherwise noted.

Antibodies to caspase 7, Bcl-2 $\alpha$ and $\mathrm{Bax}$ were purchased from NeoMarkers (Fremont, CA, USA). Antibodies for XIAP and caspase 3 were from BD Biosciences (San Diego, CA, USA). Antibodies for cleaved caspases 7 and 9 were obtained from MBL (Watertown, MA, USA). The antibodies for phosphorylated (p) I $\kappa \mathrm{B} \alpha$, pAkt, pERK1/2 and pBad were from Cell Signaling (Beverly, MA, USA). The antibodies for actin, Akt, Bad and Bcl- $\mathrm{X}_{\mathrm{L}}$ were purchased from Santa Cruz Biotechnology (Santa Cruz, CA, USA). The antibody for pJNK was from Promega and ERK1/2 was from Upstate (Lake Placid, NY, USA). The IGF-I $\beta$ receptor antibody was from Chemicon (Temecula, CA, USA). The antibody for flice-like inhibitory protein (FLIP) was from Sigma. The antibodies for prolactin, growth hormone $(\mathrm{GH})$, thyroidstimulating hormone (TSH), adrenal cortical-stimulating hormone $(\mathrm{ACTH})$ and luteinizing hormone $(\mathrm{LH})$ were from the National Hormone and Peptide Program (Torrance, CA, USA).

\section{Animals}

Adult male Wistar rats were injected (i.p.) with $70 \mathrm{mg} / \mathrm{kg}$ streptozotocin (STZ; Sigma). Control rats received vehicle only. Blood glucose concentrations were measured in the morning via tail puncture (Glucocard Memory 2; Menarini Diagnostic, Florence, Italy) to confirm the diabetic state and rats were considered to be diabetic if they maintained mean glucose levels $>300 \mathrm{mg} / \mathrm{dl}$. Rats were killed in the morning by decapitation at 1, 4, 6 and 8 weeks and the pituitaries were immediately removed and frozen on dry ice. The rats were treated according to the European Community laws for animal care and the studies were approved by the ethics committee of the institution. For immunohistochemistry studies, three rats per group were analysed and for western blot analysis, four rats/each diabetic group and eight controls were used for each analysis.

The following groups of rats were established: diabetic for 1 week (DB1W), diabetic for 4 weeks (DB4W), diabetic for 6 weeks (DB6W) and diabetic for 8 weeks (DB8W). Control rats were killed at each time-point, but as no differences were found between the control rats at different time-points in any of the studied variables (data not shown), control data were pooled for statistical analysis.

\section{Insulin ELISA}

This assay was performed according to the manufacturer's instructions (Linco Research, Inc., St Charles, MO, USA). Briefly, microtitre plates coated with pre-titred monoclonal mouse anti-rat insulin antibody were washed three times with wash buffer $(50 \mathrm{mM}$ Tris-buffered saline (TBS) containing Tween 20). Ten microlitres of prediluted standards, quality control samples and serum samples were added to wells in duplicate. Detection antibody (biotinylated anti-insulin, $80 \mu \mathrm{l}$ ) was added and the plate sealed and incubated at RT for $2 \mathrm{~h}$ while shaking. The wells were then washed and $100 \mu$ l enzyme solution (streptavidinhorseradish peroxidase conjugate) added and incubated (30 min). After washing, $100 \mu \mathrm{l}$ substrate solution $\left(3,3^{\prime}, 5,5^{\prime}\right.$-tetramethylbenzidine) were added. After colour development (approximately $15 \mathrm{~min}$ ), $100 \mu \mathrm{l}$ stop solution $(0.3 \mathrm{M} \mathrm{HCl})$ were added and the plates read at 450 and $590 \mathrm{~nm}$ on an automatic plate reader (Tecan infinite M200, Grödig Austria). The intra- and inter-assay coefficients of variation were 1.9 and 7.6 respectively. The limit of sensitivity of this assay is $0.2 \mathrm{ng} / \mathrm{ml}$. For those diabetic samples below the limit of detection, $0 \cdot 2 \mathrm{ng} / \mathrm{ml}$ was used for statistical analysis.

\section{Cell death detection ELISA}

This photometric enzyme immunoassay, for the in vitro quantification of cytoplasmic histone-associated DNA fragments (mono- and oligonucleosomes) found after 
induced cell death, was performed according to the manufacturer's (Cell Death Detection ELISA, Roche) instructions and with the following modifications. Tissue was homogenized in $300 \mu \mathrm{l}$ incubation buffer, placed on ice for $1 \mathrm{~h}$, centrifuged at $1200 \mathrm{~g}$ for $5 \mathrm{~min}$ at $4{ }^{\circ} \mathrm{C}$ and the supernatant collected. The microtitre plates were prepared by adding $100 \mu \mathrm{l}$ coating solution (anti-histone antibody) to each well and incubating for $1 \mathrm{~h}$ at RT. The coating solution was removed and $200 \mu \mathrm{l}$ incubation buffer added to each well, covered and incubated for $30 \mathrm{~min}$ at RT. The wells were then rinsed three times and the samples $(25 \mu$ sample $+75 \mu \mathrm{l}$ incubation buffer) added and incubated for $90 \mathrm{~min}$ at RT. This dilution was chosen after preliminary assays showed it to be the most adequate for detecting changes. After washing, $100 \mu \mathrm{l}$ conjugate solution (anti-DNAperoxidase) was added. The wells were covered and incubated at RT for $90 \mathrm{~min}$. After washing, $100 \mu \mathrm{l}$ substrate solution were added, mixed and incubated for $15 \mathrm{~min}$. The resulting colour was then measured at $405 \mathrm{~nm}$ on an automatic microplate analyser (Biotek Instruments, Inc., Winooski, VT, USA). Each sample was measured in duplicate in each assay. Background measurements were made and this value subtracted from the mean value of each sample. This assay has a detection limit of approximately 50 dead cells/well and results were normalized to protein levels in each sample and are reported as relative levels of cell death compared with controls. The inter- and intra-assay coefficients of variation were 8.5 and $4.3 \%$ respectively.

\section{Immunoblotting}

For western blotting, the anterior pituitary was homogenized on ice in $300 \mu$ RIPA lysis buffer with an EDTA-free protease inhibitor cocktail (Roche Diagnostics) and then centrifuged at $12000 \mathrm{~g}$ for $5 \mathrm{~min}$ at $4{ }^{\circ} \mathrm{C}$ to remove the insoluble material. Clear supernatants were transferred to a new tube and protein content measured using Bio-Rad Laboratories, Inc Protein Assay. Protein $(30-60 \mu \mathrm{g}$ ) was resolved using 10 or $12 \%$ SDS-PAGE and then transferred onto PVDF membranes (Bio-Rad). Membranes were blocked with Tris-buffered saline containing 5\% (w/v) non-fat dried milk, except for phosphorylated proteins where TBS containing 5\% BSA was used, and incubated with the primary antibody at a dilution of 1:1000. Membranes were subsequently washed and incubated with the corresponding secondary antibody conjugated with peroxidase at a dilution of 1:2000 (Pierce, Rockford, IL, USA). Bound peroxidase activity was visualized by chemiluminescence (Perkin-Elmer Life Sciences, Boston, MA, USA) and quantified by densitometry using Bio-1D (Vilber Lourmat, Marne La Vallee, France). For each assay, the results were normalized to control levels and protein loading variability normalized by rehybridizing the membrane with antibody to actin.

\section{Immunohistochemistry}

Immunohistochemistry was performed on frozen $12 \mu \mathrm{m}$ cryostat sections of pituitaries of rats that were diabetic for 8 weeks and controls mounted on positively charged slides. Sections were fixed in $4 \%$ paraformaldehyde $(w / v)$ for $20 \mathrm{~min}$ at RT, washed in TBS $+0 \cdot 1 \%$ BSA and $0 \cdot 1 \%$ Triton X-100 (this buffer was used for all subsequent washes) and blocked in TBS containing 3\% BSA and 1\% Triton X-100 for $2 \mathrm{~h}$. Sections were left overnight in a humid chamber at $4{ }^{\circ} \mathrm{C}$ with the primary antibodies, prolactin (1:2000), GH (1:1000), TSH (1:1000), LH $(1: 1000)$ or ACTH $(1: 1000)$ plus XIAP (1:500) in blocking solution. Then, sections were washed and incubated with an anti-rabbit antibody conjugated to Alexa Fluor 633 (Molecular Probes, Eugene, OR, USA; 1:2000) and antiguinea pig antibody conjugated to Alexa Fluor 488 (Molecular Probes; 1:2000) for $90 \mathrm{~min}$. Slides were incubated in the dark after the addition of the fluorochromes. The resulting signal was visualized using a confocal microscope (Leica, Madrid, Spain). Concentration curves were performed to determine the optimal concentration of primary antibody. No specific labelling was observed when the primary antibody was omitted.

To determine the approximate number of double-labelled cells, images were captured using a $63 \times$ objective and stored. In each field, the number of cells immunopositive for each hormone and those positive for hormone and XIAP were determined. Six sections per animal were analysed and approximately four fields per section. The mean percentage of double-labelled lactotrophs was then determined.

\section{Terminal dUTP nick-end labelling (TUNEL) plus immunohistochemistry}

Cell death detection assays were performed following the manufacturer's instructions (Roche). Briefly, after fixation in $4 \%$ paraformaldehyde in $0 \cdot 1 \mathrm{M}$ phosphate buffer $(\mathrm{pH} 7 \cdot 4)$, sections of pituitaries of rats which were diabetic for 8 weeks and controls were washed three times in buffer and incubated for $30 \mathrm{~min}$ with a $0 \cdot 1 \%$ sodium citrate, $0 \cdot 1 \%$ Triton X-100 solution to increase tissue permeability. Slides were again washed three times with buffer, and incubated with TUNEL solution for $90 \mathrm{~min}$ at $37^{\circ} \mathrm{C}$ in a humid chamber in the dark. After washing, the slides were incubated with antibody towards prolactin (1:2000), GH (1:1000), TSH (1:1000), LH $(1: 1000)$, ACTH $(1: 1000)$ or caspase $8(1: 250)$ in TBS containing 3\% BSA and 1\% Triton X-100 and left for $48 \mathrm{~h}$ at $4{ }^{\circ} \mathrm{C}$. The slides were incubated with Alexa Fluor antifluorescein-488 and -633-conjugated goat anti-guinea pig IgG (Molecular Probes) in blocking buffer both at a dilution of 1:1000. Finally, the slides were again washed three times before mounting in glycerol. Results were visualized with a confocal microscope and colocalization calculated as described earlier. 

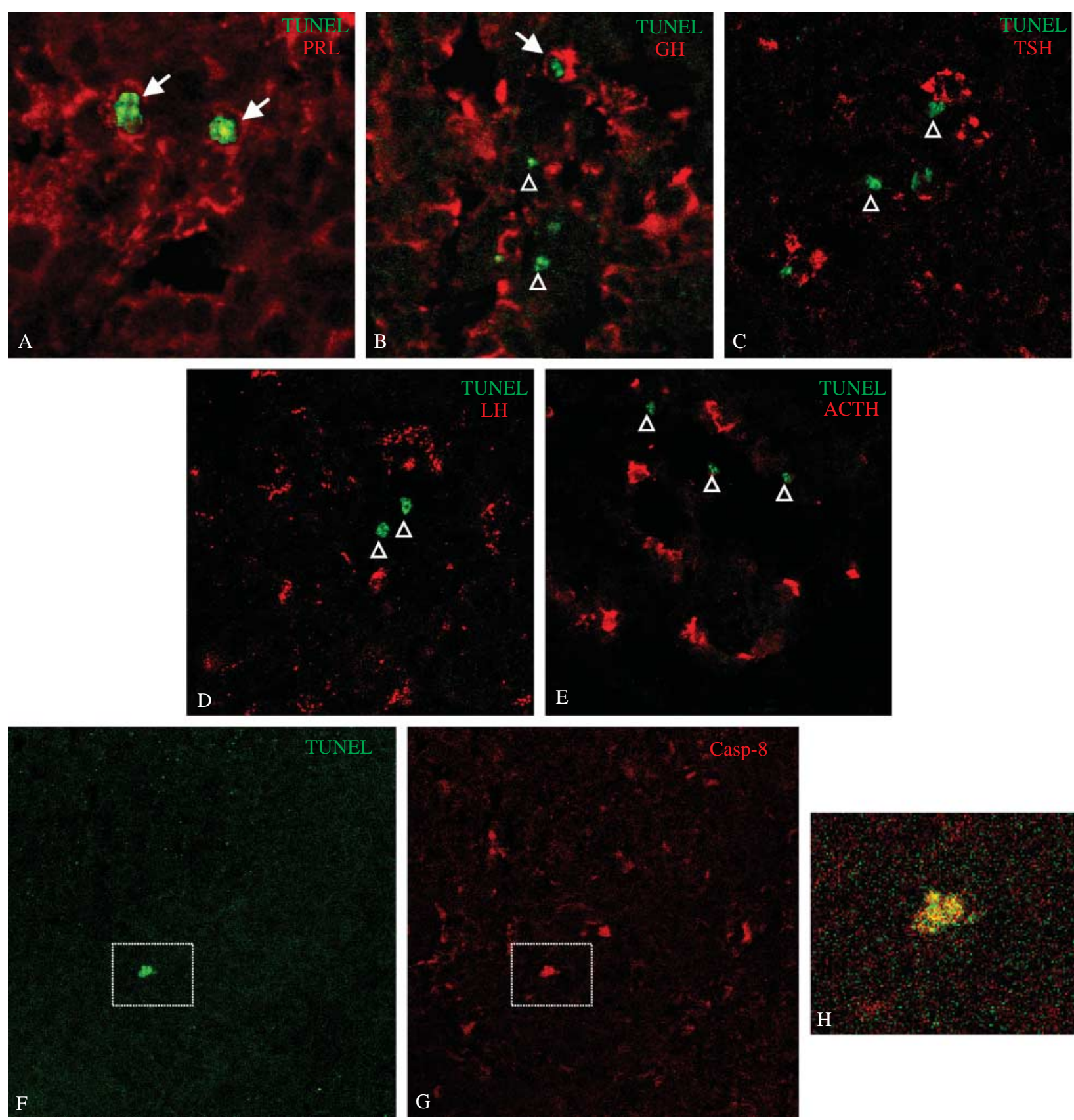

Figure 1 Photomicrographs of terminal dUTP nick-end labelling (TUNEL) and immunohistochemistry for (A) prolactin (PRL), (B) growth hormone $(\mathrm{GH})$, (C) thyroid-stimulating hormone (TSH), (D) luteinizing hormone (LH) and (E) adrenocorticotrophin-stimulating hormone $(\mathrm{ACTH})$. In the anterior pituitary of rats that were diabetic for 8 weeks TUNEL labelling (F) and caspase 8 (Casp-8) immunolabelling could be found to colocalize in the nucleus (G). The majority of the cells that were TUNEL positive expressed PRL, with a few expressing GH. No TSH, $\mathrm{LH}$ or ACTH immunopositive cells were found to be TUNEL positive. Closed arrows indicate TUNEL- and hormone-positive cells. Open arrows indicate cells that are only TUNEL positive.

\section{Statistical analysis}

The mean value of each animal was used for statistical analysis and all results were reported as mean \pm s.E.M. All western blot results were normalized to actin levels in the same sample and then to mean control levels in each assay (control $=100 \%$ ). One-way ANOVA was used for comparisons between groups followed by a Scheffé $F$ test. Significance was chosen as $P<0 \cdot 05$. 


\section{Results}

Serum glucose and insulin levels

At the time of death, glucose levels in all STZ-treated groups were higher than in the control group $(P<0 \cdot 001)$ with no difference between the diabetic groups. Insulin levels remained decreased throughout the study (ANOVA $P<0 \cdot 0001)$ and no significant differences were found between the diabetic groups (Table 1).

\section{Cell death}

Cell death in the pituitary increased significantly at 4 weeks of diabetes and remained increased throughout the rest of the study with maximum cell death being detected after 8 weeks

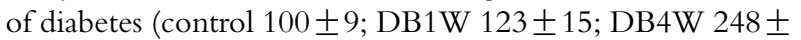

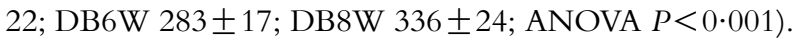

At 8 weeks of diabetes, lactotrophs were the most affected cell type (Fig. 1A), as previously reported (Arroba et al. 2003, 2005). In the pituitaries of diabetic rats, less than $10 \%$ of TUNEL-positive cells corresponded to $\mathrm{GH}$-producing cells (Fig. 1B). No TSH-, ACTH- or LH-producing cells were found to colocalize with TUNEL labelling (Fig. 1C-E).

We previously reported that at 8 weeks of diabetes, no activation of the effector caspases 3, 6 or 7 was found (Arroba et al. 2005). As caspase 8 can also act as an effector caspase (Benchoua et al. 2002), we analysed whether this caspase was localized in the nucleus of apoptotic cells. As seen in Fig. $1 \mathrm{H}$, TUNEL-labelled nuclei could be found to colocalize caspase 8 .

\section{Protein kinases}

The levels of pAkt in the pituitaries of diabetic rats increased significantly at 1 week and increased further at 6 and 8 weeks, such that the highest levels were found at 8 weeks (Fig. 2A; ANOVA $P<0 \cdot 05)$. No differences in non-phosphorylated Akt levels were found.

The levels of pERK1/2 were significantly increased in the pituitary of diabetic rats beginning at 4 weeks and remained so throughout the rest of the study (Fig. 2B; ANOVA

Table 1 Glucose and insulin concentrations in control and diabetic rats. $n=4$ for each diabetic group and $n=8$ for controls.

\begin{tabular}{lcll} 
& $\begin{array}{l}\text { Glucose concentration } \\
(\mathrm{mg} / \mathrm{dl})\end{array}$ & & $\begin{array}{l}\text { Insulin concentration } \\
(\mathrm{ng} / \mathrm{ml})\end{array}$ \\
\cline { 2 - 2 } Control & $72 \cdot 4 \pm 2 \cdot 0$ & & $1 \cdot 75 \pm 0 \cdot 18$ \\
DB1W & $515 \cdot 6 \pm 31 \cdot 2^{*}$ & $0 \cdot 23 \pm 0 \cdot 03^{+}$ \\
DB4W & $519 \cdot 6 \pm 36 \cdot 6^{*}$ & $0 \cdot 35 \pm 0 \cdot 13^{+}$ \\
DB6W & $538 \cdot 1 \pm 31 \cdot 8^{*}$ & $0 \cdot 28 \pm 0 \cdot 06^{+}$ \\
DB8W & $482 \cdot 6 \pm 46 \cdot 4^{*}$ & $0 \cdot 33 \pm 0 \cdot 05^{+}$
\end{tabular}

*ANOVA $P<0.001$ and $^{+}$ANOVA $P<0.0001$ compared with control. DB1W, 1 week of diabetes; DB4W, 4 weeks of diabetes; DB6W, 6 weeks of diabetes; DB8W, 8 weeks of diabetes.
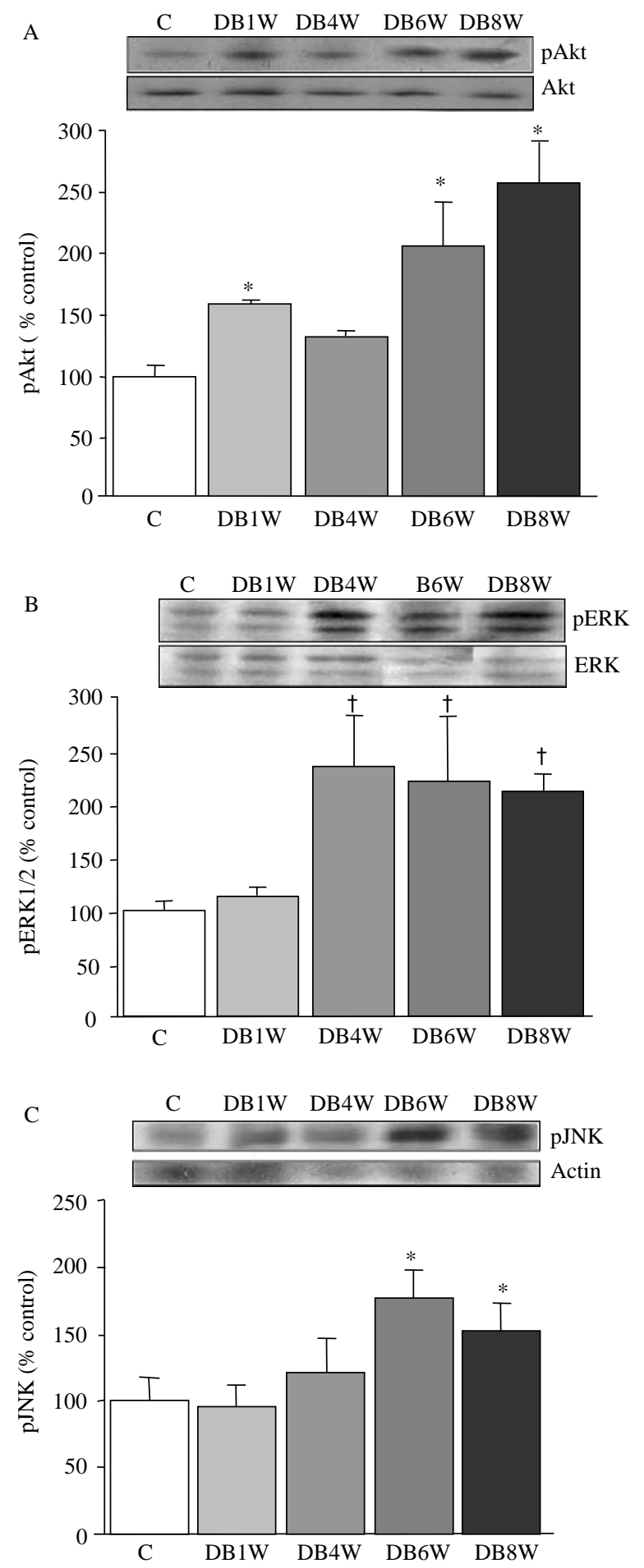

Figure 2 (A) Relative mean levels of phosphorylated (p) Akt; *ANOVA $P<0.05$ compared with control. (B) $\mathrm{p}$-ERK $1 / 2 ;{ }^{\dagger}$ ANOVA $P<0.001$ compared with control. (C) p-JNK; *ANOVA $P<0 \cdot 05$ compared with control, in the pituitary of diabetic rats as determined by western blot. C, control; DB1W, 1 week of diabetes; DB4W, 4 weeks of diabetes; DB6W, 6 weeks of diabetes; DB8W, 8 weeks of diabetes. $n=4$ for each diabetic group and $n=8$ for controls. 
A

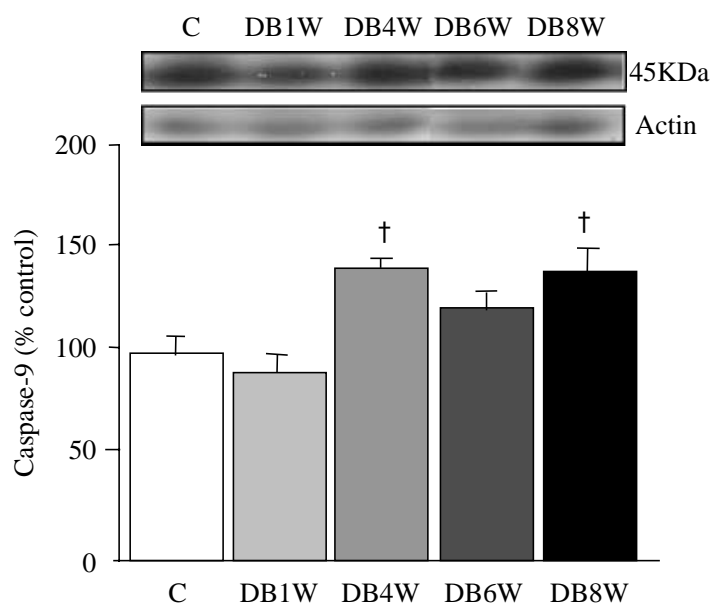

B

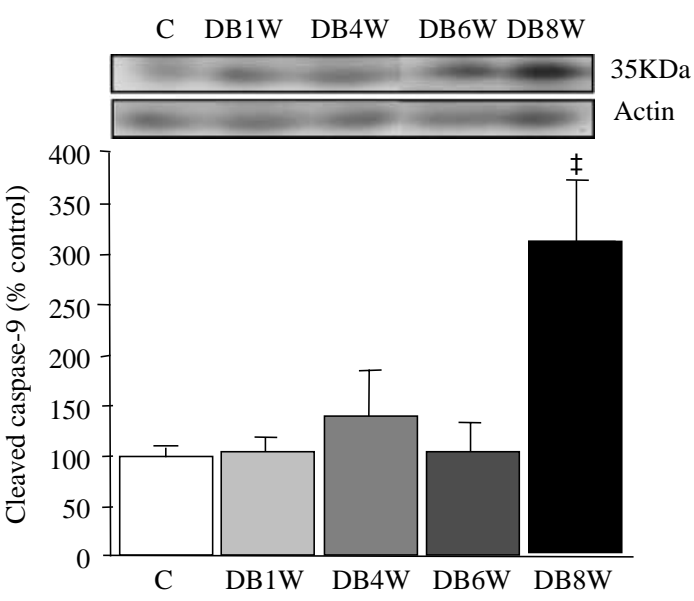

$\mathrm{D}$

C C DB1W DB4W DB6W DB8W

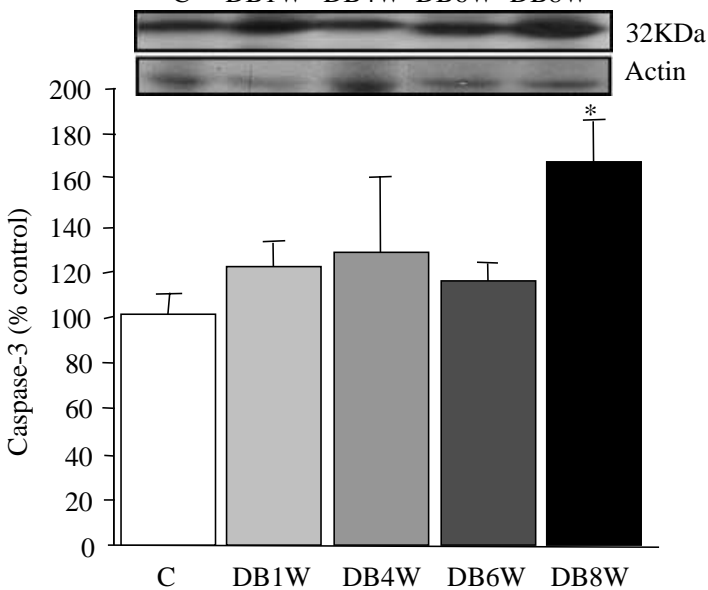

E

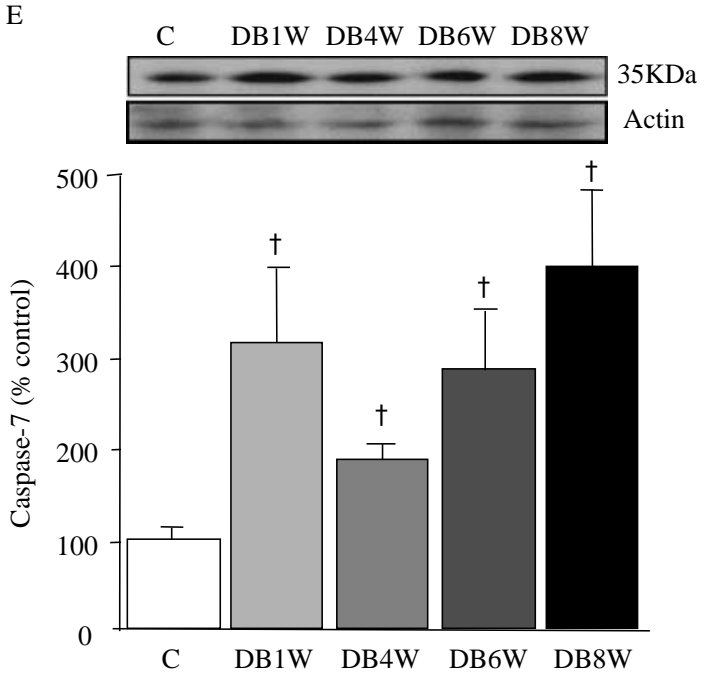

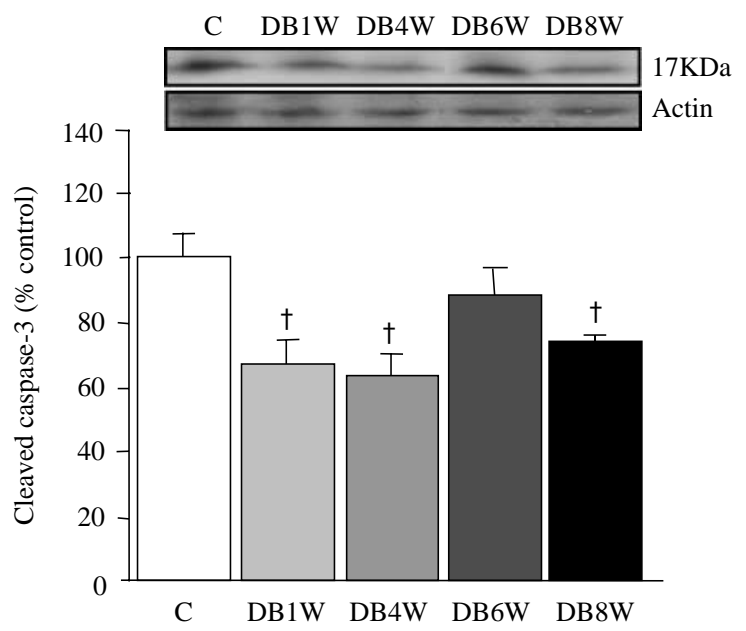

F

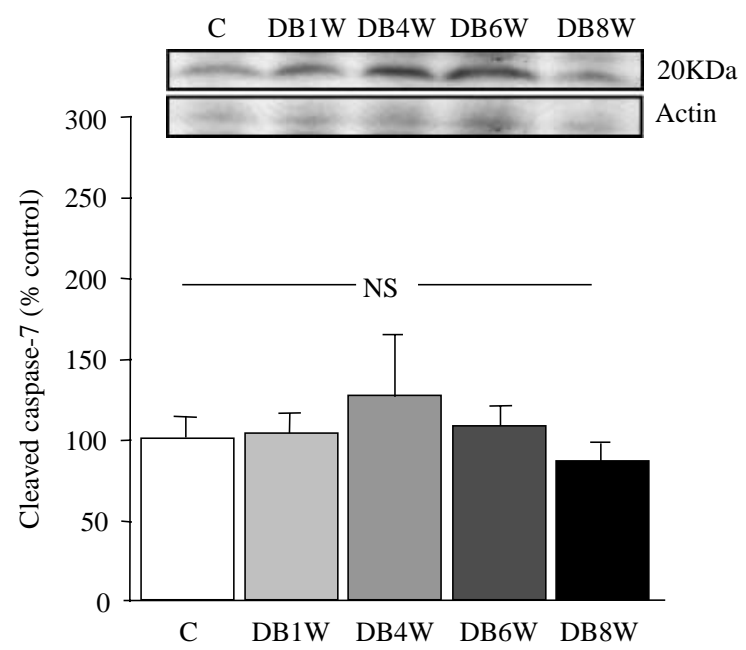


$P<0 \cdot 001)$. Non-phosphorylated ERK1/2 levels did not differ between groups.

After 6 weeks of diabetes, pJNK levels increased significantly in the anterior pituitary (Fig. 2C; ANOVA $P<0 \cdot 05$ ).

\section{Activation of caspases of the mitochondrial pathway}

Levels of the proform of caspase 9 were significantly higher at 4 and 8 weeks of diabetes (Fig. 3A; ANOVA $P<0 \cdot 01$ ), while the fragmented form (35 kDa) was significantly higher only in the pituitaries of DB8W (Fig. 3B; ANOVA $P<0 \cdot 001$ ).

Levels of the proform of caspase 3 were significantly higher at 8 weeks of diabetes (Fig. 3C; ANOVA $P<0 \cdot 05$ ), while levels of fragmented caspase $3(17 \mathrm{kDa})$ were lower in the pituitaries of groups DB1W, DB4W and DB8W compared with control rats (Fig. 3D; ANOVA $P<0 \cdot 01$ ).

Procaspase 7 levels increased significantly at 1 week of diabetes and remained so throughout the study (ANOVA $P<0 \cdot 01)$. No significant differences in the fragmented form of caspase $7(20 \mathrm{kDa})$ were found between groups (Fig. 3E and $F$ respectively).

\section{Bcl-2 protein family}

Mean concentrations of the anti-apoptotic protein, Bcl-2 $\alpha$, were significantly higher in diabetic rats at 4 and 8 weeks, while $\mathrm{Bcl}-\mathrm{X}_{\mathrm{L}}$, also anti-apoptotic, increased at 8 weeks (Table 2; ANOVA $P<0 \cdot 01$ ). Mean levels of Bax, a pro-apoptotic protein, were not significantly different between the groups at any time-point. Mean levels of BAD, also pro-apoptotic, were lower in the pituitary of diabetic rats at 1 week compared with controls and remained so throughout the study (ANOVA $P<0 \cdot 01$ ). The phosphorylated or inactivated form of this protein was higher in the pituitaries of diabetic rats at 6 and 8 weeks compared with controls (Table 2; ANOVA $P<0 \cdot 01$ ).

\section{IGF-I receptor}

The concentration of IGF-I receptor increased in the pituitary of diabetic rats at 1 week of diabetes and remained so throughout the study (Fig. 4A; $P<0 \cdot 01$ ).

\section{Apoptosis inhibitors}

No significant difference in the mean concentration of the protein FLIP was found between control and diabetic rats at any time-point (controls $100 \pm 13 \cdot 5$ vs DB1W $75 \cdot 3 \pm 16 \cdot 1$; DB4W

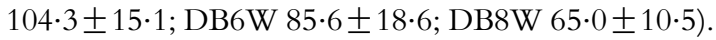

The concentration of the apoptosis inhibitor XIAP was significantly higher in the pituitaries of diabetic rats at 6 and 8 weeks after diabetes compared with controls (Fig. 4B; ANOVA $P<0 \cdot 05)$. The fragmented form $(30 \mathrm{kDa})$ of this protein was detected in the pituitaries of diabetic rats as early as the first week of diabetes.

\section{$N F K B$}

Activation of $\mathrm{NF} \kappa \mathrm{B}$ is directly related to the liberation of phosphorylated I $\mathrm{B} \mathrm{B} \alpha$. Concentrations of $\mathrm{pI} \kappa \mathrm{B} \alpha$ were $1 \cdot 6-$ fold higher in the pituitaries of diabetic rats at 6 and 8 weeks compared with controls (ANOVA $P<0 \cdot 01$; Fig. 4C).

\section{Colocalization of XIAP with caspases}

Activation of caspases 8 and 9 was increased in the pituitaries of diabetic rats (Fig. 5E and $\mathrm{K}$ ) compared with controls (Fig. 5B and $\mathrm{H}$ ). However, while XIAP was found to colocalize in caspase 9-expressing cells in pituitaries of both control and diabetic rats (Fig. 5C and $\mathrm{F}$ respectively), no colocalization of XIAP with caspase 8 was found in either group (Fig. 5I and L). Activation of both caspases 3 and 7 decreased in the pituitaries of diabetic rats (Fig. 5Q and $\mathrm{W}$ respectively) compared with controls (Fig. $5 \mathrm{~N}$ and T). XIAP colocalized with caspase 3 in both control and diabetic pituitaries (Fig. $5 \mathrm{O}$ and R), but not with caspase 7 in either group (Fig. 5U and $\mathrm{X}$ ).

As XIAP is not coexpressed with caspase 7, we analysed whether prolactin-producing cells express the activated form of this protease. As shown in Fig. $5 \mathrm{Y}$ and Z, no colocalization of prolactin and caspase 7 was found in the pituitaries of either control or diabetic rats.

\section{Cell-type-specific localization of XIAP}

As previously reported (Arroba et al. 2005), in diabetic rats, XIAP colocalized to $<1 \%$ of prolactin-containing cells (Fig. 6C). Likewise, XIAP was found to colocalize to $<1 \%$ of LH-producing cells (Fig. 6F). However, this caspase inhibitor was found to colocalize to $45 \pm 11 \%$ of $\mathrm{GH}$-producing cells (Fig. 6I). The majority of cells expressing TSH $(91 \pm 6 \%)$ or ACTH $(93 \pm 7 \%)$ coexpressed XIAP (Fig. 6L and $P$ respectively) in the pituitary of diabetic rats. In control animals, XIAP immunoreactivity was diffuse and it was found

Figure 3 (A) Relative mean levels of the intact $55 \mathrm{kDa}$ form of caspase 9 in the pituitary of control and diabetic rats; ${ }^{+} \mathrm{ANOVA} P<0 \cdot 01$. (B) Relative mean levels of the cleaved $35 \mathrm{kDa}$ form of caspase 9 in the pituitaries of control and diabetic rats; ${ }^{*} \mathrm{ANOVA} P<0 \cdot 001$. (C) Relative mean levels of the intact $32 \mathrm{kDa}$ form of caspase 3 in the pituitary of control and diabetic rats; *ANOVA $P<0 \cdot 05$. (D) Relative mean levels of the cleaved $17 \mathrm{kDa}$ form of caspase 3 in the pituitary of control and diabetic rats; ${ }^{\dagger}$ ANOVA $P<0 \cdot 01$. (E) Relative mean levels of the intact $33 \mathrm{kDa}$ form of caspase 7 in the pituitary of control and diabetic rats; ${ }^{+} \mathrm{ANOVA} P<0 \cdot 01$. (F) Relative mean levels of the cleaved $20 \mathrm{kDa}$ form of caspase 7 in the pituitary of control and diabetic rats. NS, not significant; C, control; DB1W, 1 week of diabetes; DB4W, 4 weeks of diabetes; DB6W, 6 weeks of diabetes; DB8W, 8 weeks of diabetes. $n=4$ for each diabetic group and $n=8$ for controls. 
Table 2 Mean relative protein levels of members of the Bcl-2 super family in the pituitaries of diabetic rats at different stages of evolution and control rats

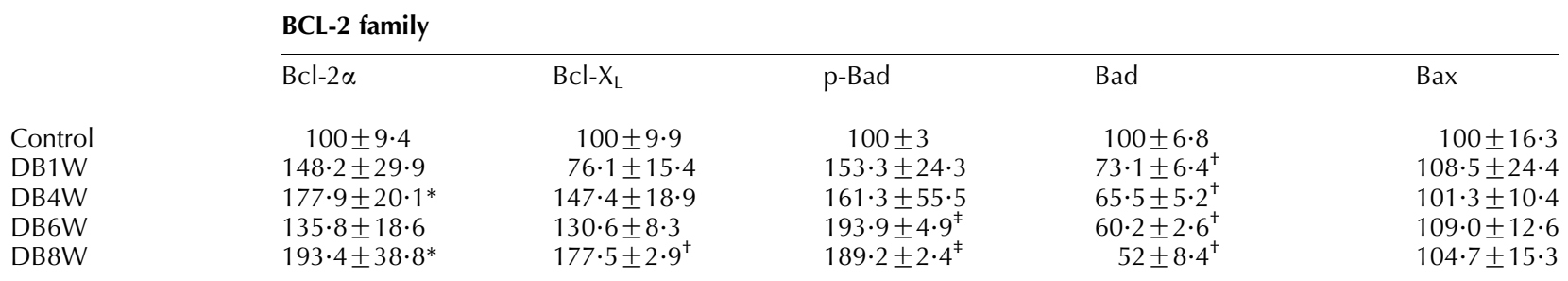

p-Bad, phosphorylated Bad; *ANOVA $P<0 \cdot 1 ;{ }^{+}$ANOVA $P<0 \cdot 01 ;{ }^{\ddagger}$ ANOVA $P<0 \cdot 001$. DB1W, 1 week of diabetes; DB4W, 4 weeks of diabetes; DB6W, 6 weeks of diabetes; DB8W, 8 weeks of diabetes. $n=4$ for each diabetic group and $n=8$ for controls.

to colocalize in approximately $10-15 \%$ of each hormoneproducing cell type, with no significant difference between cell types (not shown).

\section{Discussion}

We previously reported that cell death is increased in the anterior pituitary at 8 weeks of diabetes, but that mechanisms of cell survival and proliferation are also activated (Arroba et al. 2003, 2005). Here, we demonstrate that some pathways involved in cell survival are activated as early as 1 week after the onset of diabetes, thus occurring before an increase in cell death is detected at 4 weeks. However, other anti-apoptotic mechanisms such as increased XIAP expression are augmented after cell death increases. Indeed, in the pituitary of diabetic rats, there are temporally specific changes in cell death, cell proliferation, caspase activation and anti-apoptotic mechanisms and some of these changes are cell-type specific.

Caspases 9, 8, 7 and 3 are all expressed and activated in the normal anterior pituitary and may be involved in basal cell death in this gland. However, caspases are also reported to be involved in non-apoptotic actions, such as proliferation, differentiation and receptor internalization (Algeciras-Schimnich et al. 2002, Schwerk \& Schulze-Osthoff 2003), especially in tissues with a high rate of proliferation (Gupta 2000, Sordet et al. 2002, Huh et al. 2004, Oomman et al. 2004). Hence, these caspases could play an important role in determining the cellular composition of the pituitary in response to physiological and pathophysiological changes in the hormonal milieu (Oishi et al. 1993, Ahlbom et al. 1998, Nolan et al. 1998), such as occurs in diabetes.

Upstream mechanisms involved in cell survival and proliferation, such as phosphorylation of Akt and ERKs, are activated in the pituitary as early as 1 and 4 weeks after the onset of diabetes and this in turn could inhibit the intrinsic cell death pathway, including a decrease in cleaved caspase 3 and modifications in proteins of the Bcl-2 family (Kim \& Chung 2002, Spencer et al. 2003, Lee et al. 2005, Subramaniam et al. 2005, Yang et al. 2005). One week after diabetes onset, protein levels of Bcl-2 family members began to shift towards an anti-apoptotic ratio, with levels of the nonphosphorylated pro-apoptotic form of Bad decreasing and the anti-apoptotic proteins $\mathrm{Bcl}-2 \alpha$ and $\mathrm{Bcl}-\mathrm{X}_{\mathrm{L}}$ increasing, and continued to do so throughout the study. Although these changes may be cell-type specific, the overall shift in Bcl-2 family members to an anti-apoptotic balance in addition to a decrease in caspase 3 cleavage suggests that the intrinsic cell death pathway is most likely not involved in diabetes-induced pituitary cell death. As caspase 3 is expressed throughout the pituitary, identification of the cell types in which this decrease in caspase cleavage occurs was not possible in these studies.

Cleavage of caspase 9, which activates caspases 3 and 7 (Slee et al. 1999, Gupta 2001), increased significantly at 8 weeks of diabetes, but no activation of the effector caspases was detected. This could be due to the increase in XIAP expression since, although XIAP may not inhibit cleavage of caspase 9, it can bind to this protease and block its activity (Datta et al. 2000) and XIAP was expressed in the majority of caspase 9-expressing cells. In addition, differential cleavage of XIAP results in selective inhibition of caspases (Deveraux et al. 1999) and the $30 \mathrm{kDa}$ fragment, which contains the $\operatorname{Bir}(1-2)$ domain and can inhibit caspases 3 and 7 (Deveraux et al. 1999), became detectable at 1 week of diabetes, coincident with the decrease in caspase 3 activation.

XIAP is expressed in the majority of caspase 9-expressing pituitary cells, suggesting that it could block caspase 9 activation of downstream processes in these cells. However, activation of caspase 3 is not totally blocked by XIAP as cleaved caspase 3 also colocalizes with this inhibitor; although XIAP could be involved in the reduction of caspase 3 activation reported here. XIAP did not colocalize with caspase 8 or cleaved caspase 7 . As caspase 7 is an effector caspase and does not colocalize with XIAP and most lactotrophs do not express XIAP, we analysed whether lactotrophs express activated caspase 7. Activated caspase 7 was not expressed in lactotrophs of either normal or diabetic rats, indicating that it is not involved in the turnover of this cell type.

We previously reported that the diabetes-induced increase in lactotroph apoptosis is most likely due to activation of caspase 8 and the extrinsic cell death pathway (Arroba $e t$ al. 2005). Although XIAP can inhibit caspase 8 activation (McManus et al. 2004, Straszewski-Chavez et al. 2004), very little colocalization of this inhibitor with caspase 8 was found 

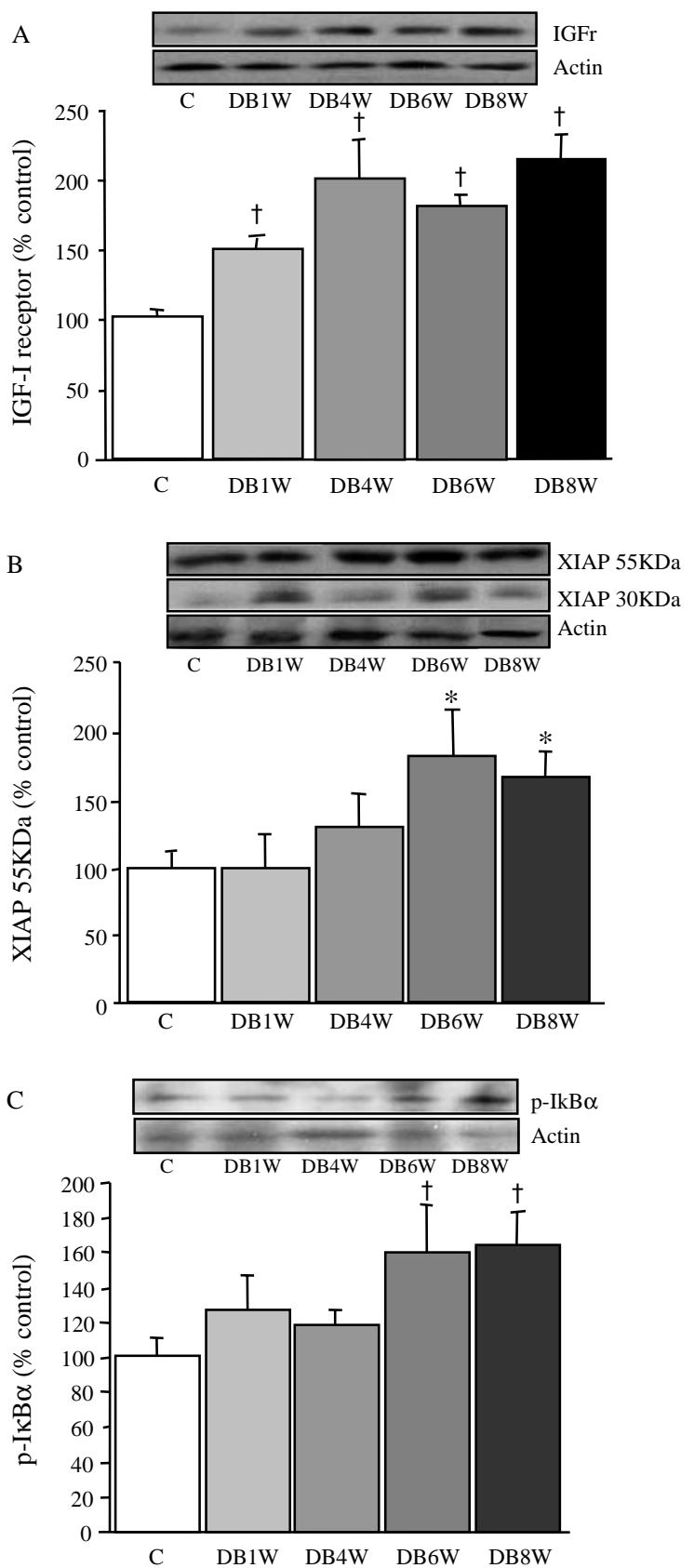

Figure 4 (A) Relative mean levels of the insulin-like growth factor (IGF)-1 receptor in control and diabetic rat pituitaries; ${ }^{+}$ANOVA $P<0.001$ compared with control. (B) Relative mean levels of the $55 \mathrm{kDa}$ form of X-linked inhibitor of apoptosis (XIAP) in control and diabetic rat pituitaries; *ANOVA $P<0.05$ compared with control. The $30 \mathrm{kDa}$ fragment was only detected in one control (shown), but became apparent as early as 1 week after the onset of diabetes in all rats. (C) Relative levels of $\mathrm{p}-\mathrm{I} \kappa \mathrm{B} \alpha$ in control and diabetic rat pituitaries; ${ }^{\dagger}$ ANOVA $P<0 \cdot 01$ compared with control. C, Control; DB1W, 1 week of diabetes; DB4W, 4 weeks of diabetes; DB6W, 6 weeks of diabetes; DB8W, 8 weeks of diabetes. $n=4$ for each diabetic group and $n=8$ for control. in the pituitary. The fact that less than $1 \%$ of lactotrophs express XIAP and levels of the caspase 8-specific inhibitor FLIP (Xiao et al. 2002) did not change suggests that lactotrophs are not protected from caspase 8-induced cell death in poorly controlled diabetes.

No increase in apoptosis of thyrotrophs, corticotrophs or gonadotrophs was observed in the pituitary of diabetic rats, while some somatotrophs were found to be TUNEL positive. In diabetic rats, virtually all thyrotrophs and corticotrophs expressed XIAP, suggesting that they may be selectively protected from cell death by this inhibitor. However, XIAP was expressed in only $50 \%$ of somatotrophs and cell death of this cell type was only slightly increased. Furthermore, less than $1 \%$ of gonadotrophs expressed XIAP and this cell type did not undergo increased death. This suggests that gonadotrophs, and possibly somatotrophs, may be protected from diabetes-induced death through other mechanisms.

Although NFKB is associated with the extrinsic cell death pathway and can be activated by pro-apoptotic signals, including activation of death receptors and tumour necrosis factor (TNF) $-\alpha$ (Xiao et al. 2002), it can also activate IAPs (Zou et al. 2004). Specifically, activation of NFKB up-regulates transcription of the XIAP gene (Stehlik 1998) and this may occur by selective activation of JNK1 (Sanna et al. 1998). Indeed, the increase in pituitary XIAP levels at 6 weeks is coincident with increased $\mathrm{NF \kappa B}$ and JNK activation.

The underlying factors involved in activation or inhibition of these pathways remain to be determined. One plausible candidate for the activation of Akt and MAPK pathways, which in turn could explain the changes in $\mathrm{Bcl}-2$ proteins and inactivation of caspase 3, is IGF-I. Although circulating levels of IGF-I are reduced in this diabetic rat model (Olchovsky et al. 1991, Busiguina et al. 1996), pituitary IGF-I content increases (Olchovsky et al. 1991). Furthermore, we found pituitary IGF-I receptor levels to be increased at 1 week of diabetes, suggesting that the sensitivity to this cell survival factor may possibly be increased. IGF-I has been shown to inhibit high glucose-induced activation of caspase 3 and apoptosis (Russell et al. 1999). However, while rapid responses could be directly related to changes in glucose or insulin levels, some of the observed changes are delayed up to 8 weeks, while others are dynamic, increasing and decreasing at various time-points. These dynamic or delayed changes cannot be explained by the increase in glucose or decrease in insulin levels as these changes are rapid and are not modified during the study period. Likewise, circulating levels of TNF$\alpha$, which is involved in diabetes-induced cell death (Chen \& Goeddel 2002) and apoptosis of lactotrophs (Candolfi et al. 2002), are increased by the first week of diabetes and remain elevated (Arroba et al. 2006). However, TNF- $\alpha$ concentrations in the anterior pituitary do not increase until the eighth week of diabetes (Arroba et al. 2006) and this could be involved in the delayed changes observed in this gland. It is highly conceivable that more than one factor is involved in the numerous modifications observed here and that each 

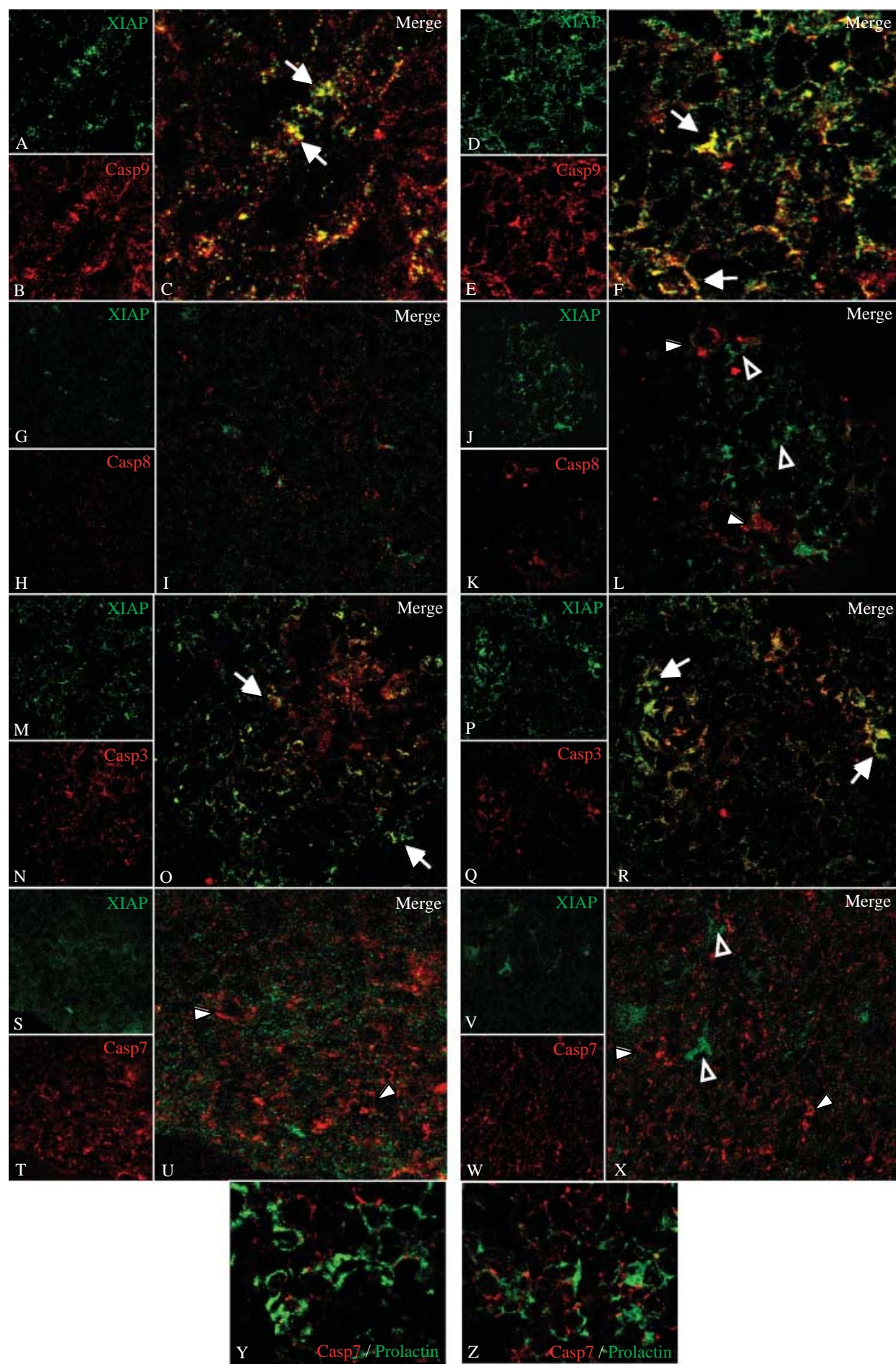

Figure 5 Photomicrographs of immunohistochemistry for X-linked inhibitor of apoptosis (XIAP) and caspases in the anterior pituitary of rats that were diabetic for 8 weeks and controls. XIAP and caspase 9 (Casp9) in a control (A-C) and diabetic rat (D-F). XIAPand caspase 8 (Casp8) in a control (G-I) and diabetic rat (J-L). XIAP and caspase 3 (Casp3) in a control (M-O) and diabetic rat (P-R). XIAP and caspase 7 (Casp7) in a control (S-U) and diabetic rat ( $\mathrm{V}-\mathrm{X})$. Immunohistochemistry for caspase 7 and prolactin in the pituitary of a control (Y) and diabetic rat (Z). Closed arrows indicate cells that are double labelled for both XIAP and caspase. Open arrowheads indicate cells that are only labelled for XIAP. Closed arrowheads indicate cells that are only expressing caspase. 

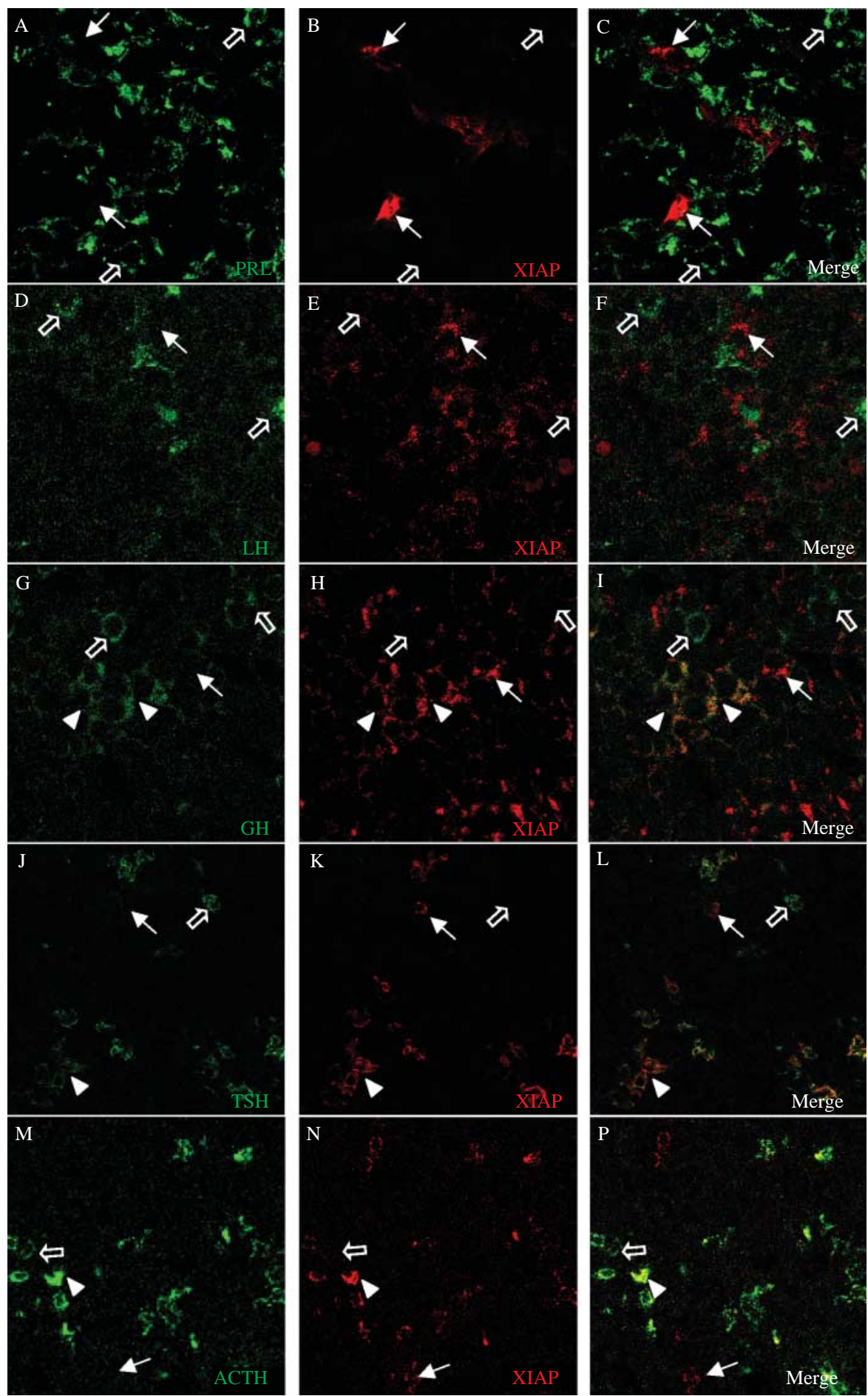

Figure 6 Photomicrographs of immunohistochemistry for X-linked inhibitor of apoptosis (XIAP; B,E,H,K,N) and prolactin (PRL, A), growth hormone $(\mathrm{GH} ; \mathrm{G})$, luteinizing hormone $(\mathrm{LH} ; \mathrm{D})$, thyroid-stimulating hormone $(\mathrm{TSH} ; \mathrm{J})$ or adrenocorticotrophin-stimulating hormone (ACTH; $\mathrm{M})$ in the anterior pituitary of rats that were diabetic for 8 weeks. There was very little colocalization $(<1 \%$ of cells) of PRL or LH with XIAP (C and $\mathrm{F}$ respectively) in the anterior pituitary of diabetic rats. However, XIAP was found to colocalize in approximately $50 \%$ of $\mathrm{GH}$ (I)- and $>$ $90 \%$ of TSH (L)- and ACTH (P)-producing cells. Open arrows indicate cells that are only expressing hormone and closed arrows indicate cells that are only expressing XIAP. Arrowheads indicate examples of double-labelled cells. 
pituitary cell type may be responding differently to each factor.

One might speculate that rapid activation of cell survival mechanisms may function to protect this gland from shortterm or transient events, while other mechanisms are invoked to confront prolonged pathophysiological situations. Furthermore, at least some of these mechanisms are cell-type specific and could explain why some pituitary cell types do not undergo increased apoptosis in poorly controlled diabetes. Indeed, thyrotrophs, gonadotrophs and corticotrophs are more resistant to diabetes-induced cell death. While increased expression of XIAP may be involved in the protection of thyrotrophs and corticotrophs, gonadotrophs do not express this caspase inhibitor, supporting the hypothesis of cellspecific mechanisms.

\section{Funding sources}

This work was funded by grants from Fondo de Investigación Sanitaria (PI04/0817 and PI05/1268), Ministerio de Educación (SAF2002-03324), Fundación de Investigación Médica Mutua Madrileña and Fundación de Endocrinología y Nutrición. A M L-S is supported by a post-medical training fellowship from Fondo de Investigación Sanitaria. J A C is supported by the Biomedical Investigation Program of the Consejería de Sanidad y Consumo de la Comunidad de Madrid. The authors verify that there is no conflict of interest that would prejudice the impartiality of these studies.

\section{References}

Ahlbom E, Grandison L, Zhivotovsky B \& Ceccatelli S 1998 Termination of lactation induces apoptosis and alters the expression of the Bcl-2 family members in the rat anterior pituitary. Endocrinology 139 2465-2471.

Algeciras-Schimnich A, Barnhart BC \& Peter ME 2002 Apoptosisindependent functions of killer caspases. Current Opinion in Cell Biology 14 721-726.

Allen DA, Yaqoob MM \& Harwood SM 2005 Mechanisms of high glucoseinduced apoptosis and its relationship to diabetic complications. Journal of Nutritional Biochemistry 16 705-713.

Arroba AI, Frago LM, Pañeda C, Argente J \& Chowen JA 2003 The number of lactotrophs is reduced in the anterior pituitary of streptozotocin-induced diabetic rats. Diabetologia 46 634-638.

Arroba AI, Frago LM, Argente J \& Chowen JA 2005 Activation of caspase 8 in the pituitaries of streptozotocin-induced diabetic rats: implication in increased apoptosis of lactotrophs. Endocrinology 146 4417-4424.

Arroba AI, Lechuga-Sancho AM, Frago LM, Argente J \& Chowen JA 2006. Increased apoptosis of lactotrophs in streptozotocin-induced diabetic rats is followed by increased proliferation. Journal of Endocrinology in press.

Ashkanazi A \& Dixit VM 1998 Death receptor: signaling and modulation. Science 281 1305-1308.

Benchoua A, Couriaud C, Guegan C, Tartier L, Couvert P, Friocourt G, Chelly J, Menissier-de Murcia J \& Onteniente B 2002 Active caspase-8 translocates into the nucleus of apoptotic cells to inactivate poly(ADPribose) polymerase-2. Journal of Biological Chemistry 277 34217-34222.

Bestetti G, Locatelli V, Tirone F, Rossi GL \& Müller EE 1985 One month of streptozotocin-diabetes induces different neuroendocrine and morphological alterations in the pituitary axis of male and female rats. Endocrinology 117 208-216.
Boldin MP, Goncharov TM, Goltsev YV \& Wallach D 1996 Involvement of $\mathrm{MACH}$, a novel MORT1/FADD-interacting protease, in Fas/APO-1- and TNF receptor-induced cell death. Cell 85 803-815.

Bonny C, Borsello T \& Zine A 2005 Targeting the JNK pathway as a therapeutic protective strategy for nervous system diseases. Reviews in the Neurosciences 16 57-67.

Busiguina S, Chowen JA, Argente J \& Torres-Aleman I 1996 Specific alterations of the insulin-like growth factor I system in the cerebellum of diabetic rats. Endocrinology 137 4980-4987.

Candolfi M, Zaldivar V, De Laurentiis A, Jaita G, Pisera D \& Seilicovich A 2002 TNF-alpha induces apoptosis of lactotropes from female rats. Endocrinology 143 3611-3617.

Chen G \& Goeddel DV 2002 TNF-R1 signaling: a beautiful pathway. Science $2961634-1635$.

Datta R, Oki E, Endo K, Biedermann V, Ren J \& Kufe D 2000 XIAP regulates DNA damage-induced apoptosis downstream of caspase-9 cleavage. Journal of Biological Chemistry 275 31733-31738.

Deveraux QL, Leo E, Stennicke HR, Welsh K, Salvensen GS \& Reed JC 1999 Cleavage of human inhibitor of apoptosis protein XIAP results in fragments with distinct specificities for caspases. EMBO Journal 18 5242-5251.

Fernandez M, Sanchez-Franco F, Palacios N, Sanchez I, Fernández I \& Cacicedo L 2004 IGF-I inhibits apoptosis through the activation of the phosphatidylinositol 3-kinase/Akt pathway in pituitary cells. Journal of Molecular Endocrinology 33 155-163.

Fernandez M, Sanchez-Franco F, Palacios N, Sanchez I \& Cacicedo L 2005 IGF-I and vasoactive intestinal peptide (VIP) regulate cAMP-response element-binding protein (CREB)-dependent transcription via the mitogen-activated protein kinase (MAPK) pathway in pituitary cells: requirement of Rap1. Journal of Molecular Endocrinology 34 699-712.

Gerhardinger C, McClure KD, Romeo G, Podesta F \& Lorenzi M 2001 IGF-I mRNA and signaling in the diabetic retina. Diabetes 50 175-183.

Gupta S 2000 Suicidal journey in the Fas (t) track. Recent Research and Developmental Immunology 2 11-19.

Gupta S 2001 Molecular steps of death receptor and mitochondrial pathways of apoptosis. Life Sciences 69 2957-2964.

Huh JR, Vernooy SY, Yu H, Yan N, Shi Y, Guo M \& Hay BA 2004 Multiple apoptotic caspase cascades are required in nonapoptotic roles for Drosophila spermatid individualization. PLoS Biology 2 43-53.

Kim D \& Chung J 2002 Akt: versatile mediator of cell survival and beyond. Journal of Biochemistry and Molecular Biology 35 106-115.

Lee JS, Lee JJ \& Seo JS 2005 HSP70 deficiency results in activation of c-Jun $\mathrm{N}$-terminal kinase, extracellular signal-regulated kinase, and caspase- 3 in hyperosmolarity -induced apoptosis. Journal of Biological Chemistry 280 6634-6641.

McManus DC, Lefevre CA, Cherton-Hovart G, St-Jean M, Kandimalla ER, Agrawal S, Morris SJ, Durkin JP \& Lacasse EC 2004 Loss of XIAP protein expression by RNAi and antisense approaches sensitizes cancer cells to functionally diverse chemotherapeutics. Oncogene 23 8105-8117.

Nolan LA, Kavanagh E, Lightman SL \& Levy A 1998 Anterior pituitary cell population control: basal cell turnover and the effects of adrenalectomy and dexamethasone treatment. Journal of Neuroendocrinology 10 207-215.

Oishi Y, Okuda M, Takahashi H, Fujii T \& Mosii S 1993 Cellular proliferation in the anterior pituitary gland of normal adult rats: influences of sex, estrous cycle, and circadian change. Anatomical Record 235 111-120.

Olchovsky D, Bruno JF, Gelato MC, Song J \& Berelowitz M 1991 Pituitary insulin-like growth factor-I content and gene expression in the streptozotocin-diabetic rat: evidence for tissue-specific regulation. Endocrinology 128 923-928.

Oomizu S, Takeuchi S \& Takahashi S 1998 Stimulatory effect of insulin-like growth factor I on proliferation of mouse pituitary cells in serum-free culture. Journal of Endocrinology 157 53-62.

Oomman S, Finckbone V, Dertien J, Attridge J, Henne W, Medina M, Mansouri B, Singh H, Strahlendorf H \& StrahlendorfJ 2004 Active caspase3 expression during postnatal development of cerebellum is not systematically or consistently associated with apoptosis. Journal of Comparative Neurology 476 154-173. 
Russell JW, Sullivan KA, Windebank AJ, Herrmann DN \& Feldmann FL 1999 Neurons undergo apoptosis in animal and cell culture models of diabetes. Neurobiology of Disease 6 347-363.

Sanna MG, Duckett CS, Richter BW, Thompson CB \& Ulevitch RJ 1998 Selective activation of JNK is necessary for the anti-apoptotic activity of hILP. PNAS 95 6015-6020.

Schwerk C \& Schulze-Osthoff K 2003 Non-apoptotic functions of caspases in cellular proliferation and differentiation. Biochemical Pharmacology $\mathbf{6 6}$ 1453-1458.

Slee EA, Harte MT, Kluck RM, Wolf BB, Casiano CA, Newmeyer DD, Wang H, Reed JC, Nicholson DW \& Alnemri ES 1999 Ordering the cytochrome c-initiated caspase cascade: hierarchical activation of caspase$2,-3,-6,-7,-8$ and -10 in a caspase- 9 dependent manner. Journal of Cell Biology 144 281-292.

Sordet O, Rebe C, Plenchette S, Zermati Y, Hermine O, Vainchenker W, Garrido C, Solary E \& Dubrez-Daloz L 2002 Specific involvement of caspases in the differentiation of monocytes into macrophages. Blood 100 4446-4453.

Spencer JP, Rice-Evans C \& Williams RJ 2003 Modulation of pro-survival $\mathrm{Akt} /$ protein kinase $\mathrm{B}$ and ERK1/2 signaling cascades by quercetin and its in vivo metabolites underlie their action on neuronal viability. Journal of Biological Chemistry 278 34783-34793.

Stehlik C 1998 Nuclear factor (NF)-kappaB-regulated X-chromosome-linked iap gene expression protects endothelial cells from tumor necrosis factor alpha-induced apoptosis. Journal of Experimental Medicine 188 211-216.

Straszewski-Chavez SL, Abrahams VM, Funai FF \& Mor G 2004 X-linked inhibitor of apoptosis (XIAP) confers human trophoblast cell resistance to Fas-mediated apoptosis. Molecular Human Reproduction 10 33-41.

Subramaniam S, Shahani N, Strelau J, Laliberte C, Brandt R, Kaplan D \& Unsicker K 2005 Insulin-like growth factor 1 inhibits extracellular signalregulated kinase to promote neuronal survival via the phosphatidylinositol 3-kinase/protein kinase A/c-Raf pathway. Journal of Neuroscience $\mathbf{1 6}$ $2838-2853$.
Valimaki M, Liewendahl K, Nikkanen P \& Pelkonen R 1999 Hormonal changes in severely uncontrolled type 1 (insulin-dependent) diabetes mellitus. Scandinavian Journal of Clinical and Laboratory Investigation $\mathbf{5 1}$ 385-393.

Wajant H 2002 The Fas signaling pathway: more than a paradigm. Science $\mathbf{2 9 6}$ $1635-1636$.

Xiao CW, Asselin E \& Tsang BK 2002 Nuclear factor kappaB-mediated induction of Flice-like inhibitory protein prevents tumor necrosis factor alpha-induced apoptosis in rat granulose cells. Biology of Reproduction $\mathbf{6 7}$ 436-441.

Yang JY, Walicki J, Michod D, Dubuis G \& Widmann C 2005 Impaired Akt activity down-modulation, caspase-3 activation, and apoptosis in cells expressing a caspase-resistant mutant of RasGAP at position 157. Molecular Biology of the Cell 16 3511-3520.

Yoon S \& Seger R 2006 The extracellular signal-regulated kinase: multiple substrates regulate diverse cellular functions. Growth Factors 24 21-44.

Zamzami N \& Kroemer G 2001 The mitochondrion in apoptosis: how pandora's box opens. Nature Reviews. Molecular Cell Biology 2 67-71.

Zdychova J \& Komers R 2005 Emerging role of Akt kinase/protein kinase B signaling in pathophysiology of diabetes and its complications. Physiological Research 54 1-16.

Zou T, Rao JN, Guo X, Liu L, Zhang HM, Strauch ED, Bass BL \& Wang JY 2004 NF-kappaB-mediated IAP expression induces resistance of intestinal epithelial cells to apoptosis after polyamine depletion. American Journal of Physiology. Cell Physiology 286 C1009-C1018.

\section{Received in final form 2 October 2006 \\ Accepted 10 October 2006 \\ Made available online as an Accepted Preprint 13 October 2006}

